\title{
NIH takes Stewart and Feder off the misconduct beat
}

\begin{abstract}
Washington. The US National Institutes of Health (NIH) have reassigned two controversial scientists and told them to end a decade of work investigating scientific misconduct.
\end{abstract}

The scientists, Ned Feder and Walter Stewart, hope to overturn a decision by their bosses at the National Institute of Diabetes and Digestive and Kidney Diseases (NIDDK) to abolish their two-man biophysical histology laboratory. But it is not clear how hard their supporters, including Representative John Dingell (Democrat, Michigan), who chairs the committee that oversees NIH, will fight to reinstate them. The men have survived previous attempts by NIH to constrain their activities, but their latest foray into allegations of plagiarism against historian Stephen Oates may have been the last straw.

Feder and Stewart became part of a growing debate during the 1980 s on the nature and extent of scientific misconduct by analysing the involvement of co-authors on fraudulent papers written by John Darsee during three years at Emory and Harvard universities. The paper was published after a three-year odyssey through the scientific press (Nature 325, 207; 1987), and the scientists soon became a magnet for those with allegations of scientific impropriety. Their most controversial role was as consultants to a four-year investigation by Dingell's oversight and investigations subcommittee into the contents of a 1986 Cell paper, of which Nobel laureate David Baltimore was one of the co-authors. The government's final report on the case is pending and may be issued this summer.

On 9 April, the two men were told to turn over their misconduct files to the Office of Research Integrity (ORI), formed last summer as a successor to the Office of Scientific Integrity to investigate allegations of scientific misconduct by those with grants from NIH or its sister agencies within the US Public Health Service. Feder has been reassigned with effect from 10 May to a job reviewing funding proposals from outside scientists, and Stewart is to be transferred to a biophysical chemistry laboratory within the institute.

The reassignment is being made for three reasons, according to a press spokeswoman for the institute. "History is not part of our mission", says Elizabeth Singer of NIDDK. "The Oates affair takes them well beyond biomedical research." In addition, she says that the creation of ORI to investigate mis- conduct "makes it unnecessary for anyone to go to Wally and Ned" with their complaints. Finally, NIDDK must lose 30 posts in the next year as its part of a governmentwide slimming down by the Clinton administration, and the biophysical histology laboratory was deemed expendable.

Both men say that they will fight to retain their current positions and to continue their work on misconduct. "The problem isn't

\section{IMAGE UNAVAILABLE FOR COPYRIGHT REASONS}

\section{Promega extends fight with Roche over Taq enzyme}

Washington. Promega Corporation of Madison, Wisconsin, is challenging the validity of a key patent held by Hoffmann-La Roche of Nutley, New Jersey, for the heat-stable enzyme Taq DNA polymerase - the enzyme that drives the polymerase chain reaction (PCR).

A victory by Promega, who filed papers last week in US district court in New Jersey, would loosen the grip that Roche and its exclusive licensee, Perkin-Elmer Corporation of Norwalk, Connecticut, now has on

the sale and pricing of the enzyme when it is used in PCR. Promega and six other companies have licences from Roche to sell Taq polymerase for less commercially lucrative purposes such as DNA sequencing.

The patent for Taq polymerase was issued to scientists at Cetus Corporation of Emeryville, California, in 1989 and purchased by Roche in 1991 when Cetus sold its PCR business to Roche for $\$ 300$ million. It covers the purified enzyme Taq DNA polymerase either isolated from the bacterium Thermus aquaticus or derived from a genetically engineered organism containing a gene that codes for the production of the enzyme.

Last autumn, Roche sued Promega as part of its attempt to clamp down on those thought to be infringing on its patent rights. Roche claims that Promega is violating a 1990 licensing agreement between the two companies under which Promega is permitted to manufacture and sell Taq polymerase as a stand-alone enzyme for purposes other than PCR.

Promega has refused to discuss the basis for its challenge, but Randall Dimond, chief technology officer for Promega, says that his company has found evidence in the literature that $T a q$ polymerase was purified from the bacterium T. aquaticus before Cetus became involved. In particular, he cites a paper by four Russian scientists published in Biokhimiya $(45,644-651 ; 1980)$ and reprinted that year in Biochemistry that was entitled "Isolation and properties of DNA polymerase from extremely thermophilic bacterium Thermus aquaticus YT1".

Dimond believes that Roche sued his company because it is concerned that people are buying the enzyme from cheaper sources than Perkin-Elmer and using it in PCR. Promega is the second largest supplier of Taq polymerase worldwide (behind PerkinElmer) and its prices are 50 per cent lower than those of Perkin-Elmer. Christine Aylward, a spokeswoman for Roche Molecular Systems Inc., says that Promega is challenging Roche's Taq patent to divert attention from the first lawsuit.

Diane Gershon 